\title{
Using transportation problem in humanitarian supply chain to prepositioned facility locations: a case study in the Democratic Republic of the Congo
}

\author{
Jean-Claude Baraka Munyaka ${ }^{1}$ [D $\cdot$ Venkata Seshachala Sarma Yadavalli ${ }^{1}$
}

Received: 9 June 2020/Revised: 15 August 2020/Published online: 2 September 2020

(C) The Society for Reliability Engineering, Quality and Operations Management (SREQOM), India and The Division of Operation and Maintenance, Lulea University of Technology, Sweden 2020

\begin{abstract}
Over the last two decades, the Democratic Republic of Congo (DRC) has been plague by conflicts that has caused the lives of millions of Congolese in the eastern parts of the country while displacing many more. These multifaceted man-made conflicts have contributed to the crumbling of the regional infrastructures and transportation system, to insecurity, poverty and many more. Despite the region huge human, minerals, forestry and energy potential for development, the DRC authorities and international organizations operating in the region have largely failed to ensure farmers, miners, scholars of the Eastern Congo safety during their day to day routine. It is for such reason, humanitarian reliefs are needed to supplement any shortfalls in term of foods, medicines, shelters and others. This research aimed at optimizing prepositioned relief supply to the region. This study intends first to identify potential prepositioned relief locations in the three most conflicts heated provinces in the Eastern Congo (Ituri, South Kivu and North Kivu). Then, the study uses transportation problem in minimizing the total costs and the total time of distributing goods from supply points (sources) to a number of demand points (destinations). The model outcome reveals that by incorporating all transportation modes into the operation, humanitarian organizations are more flexible against infrastructures, health or security challenges that often ravage Eastern Congo.
\end{abstract}

Jean-Claude Baraka Munyaka

u19410507@tuks.co.za

University of Pretoria, Pretoria, Gauteng, South Africa
Keywords Humanitarian logistics - Disaster relief operations · Democratic Republic of Congo - Lean manufacturing $\cdot$ Prepositioned facility locations

\section{Introduction}

Disaster relief supply chain is the movement of personnel and humanitarian supplies to affected zones in order to alleviate the suffering of the vulnerable (Strawderman and Eksioglu 2009).

As documented by several accredited researches, the impacts of natural and man-made disasters in the Southern African Development Community (SADC) region have been in the rise, with the latest prediction pointing towards more events in the future. However, Starr and Van Wassenhove (2014) note at a source an apparent lack of organized plan to reach victims and especially in the aftermath of a disaster. Among the SADC country most affected by natural and man-made disasters is the Democratic republic of Congo (DRC).

This resource rich country in the central Africa, a country in the size of a continent is the access point between the East and the West of the African continent. Unfortunately, the country has been a subject of neverending conflicts that have caused the loss of many lives while subsequently straining humanitarian organizations efforts (Kembro 2012). Table 1 has revealed that the Democratic Republic of Congo has suffered over two hundred natural and man-made disasters, with nearly 6 million people being killed by man-made disasters only (WFP 2013) and 3 million more being displaced (WFP 2013). The conflicts in the DRC were inherited from the country independence in 1960 . In the last 25 years 
Table 1 DR congo man-made and natural disaster values from OFDA CRED international disaster database value for all SADC countries between 1900 and 2016

\begin{tabular}{lllrrr}
\hline Country & Natural disaster & Number of events & Killed & Total affected & Damage (US\$ 000) \\
\hline DRC & Man-made & 116 & $5,872,000$ & $2,600,000$ & \\
& Natural & 102 & 10,381 & 272,096 & 21,600 \\
Total & & 218 & $5,882,381$ & $2,872,096$ & 21,600 \\
\hline
\end{tabular}

however, the country has experienced a bloodier and more deadly arm conflicts in the Eastern side of the DRC, specifically in the North, South Kivu and the Ituri Province.

Looking into the proportion of Natural and Man-Made disasters in the SADC region, the Democratic Republic of Congo is the second country with the greatest number of both type disasters with 218 cases.

According to Oxfam (2014), the 6 million deaths toll, could be even higher according to other reputable bodies estimates, is largely attributed to the secondary effects of prolonged conflict, impacting the country, its inhabitants, its foods security, its health care infrastructures with as causes the contamination of drinking water as well as the resurface of poor sanitation practices that has led to epidemics such as Cholera, measles or even Ebola. Other notable consequences include the inaccessibility of relief organizations to disaster-prone areas in the eastern Congo due to poor infrastructures (Mpita et al. 2016), leading to relief supplies scarcities in the affected region (WFP 2012).

DRC supply chain and logistics are viewed as a major challenge. To face all those challenges, a new style of preparedness is needed by humanitarian organizations operating in DRC in order to respond timely to the predictable demands caused by on-going conflicts. This research aim is the optimization of prepositioned relief supply to the region. To achieve the above aim, the following objectives will be developed:

1. The identification of potential prepositioned relief locations targeting the three most conflicts heated provinces in the Eastern Congo (Ituri, South Kivu and North Kivu).

2. Then, the development of a transportation model that minimizes the humanitarian supply chain cost and time.

\section{Literature reviews}

\subsection{Importance of humanitarian logistics}

This study focuses on the development of humanitarian logistics operations in one of the most vulnerable regions in the African continent. This operation assists minimize the human suffering and death caused by natural and manmade disasters (Balcik and Beamon 2008). Strawderman and Eksioglu (2009) defined Humanitarian logistics as the process of planning, implementing and controlling the efficiency, the cost effectiveness of goods flow and storage as well as materials and related information from their origins to their consumptions.

Strawderman and Eksioglu (2009) further states that although humanitarian logistics assure that the planning is done effectively, the movements of personnel and supplies are completed by disaster relief supply chains, which directly affect the performance of humanitarian aid. Disaster relief chains is defined by Thomas (2004) as the systems and processes involved in mobilizing people, resources, skills and knowledge to help vulnerable people affected by natural disasters and complex emergencies. The function incorporates a range of activities such as preparedness, planning, procurement, transport, warehousing, tracking and tracing, customs and clearance (Thomas 2004).

Tatham and Houghton (2011) note an increase in recent years of the interest by the international academic community on the challenges faced worldwide in term of humanitarian logistics (Kovács and Spens 2009), especially researches and publications that focus on real lives case scenarios. zooming into the increase globally in term of natural and man-made disasters as well as to the current covid-19 challenge that have ravages the world and its economy, the use of supply chain management is able to assist communities' pre- or post-disaster recovery in different means (Tatham and Houghton 2011). Among the means, Supply chain is able to resolve issues related to "the lack of proper planning, communication and coordination challenges, the inaccessibility of regions and cities affected by conflicts, the unpredictable nature of new conflicts, and security issues caused by the conflict" (RDC Humanitaire 2020; Oxfam International 2014; Kembro 2012). Both humanitarian logistics and supply chain techniques deserve to work hand in hand in order to optimize timely relief supply in the region.

Furthermore, limited reviewed papers have explicitly targeted the regional transportation problems and ways to 
optimize their efficiency (quick action) and effectiveness (low-cost) during a humanitarian operation. Transportation problem either maximize or minimize the objective function given the set of alternatives. Alternatives (feasible or constraint region) is essential in order to minimize the transportation cost and time in SADC region (Figs. 1, 2).

\subsection{Case study of the (DR Congo)}

For the past 20 years, the eastern part of Congo (North, South Kivu and Ituri) has encountered, according to BBC magazine report, the bloodiest conflict in the world since World War two (WW2). These conflicts have led to loss of lives, civilian displacements as well as the regional economic mayhems. This country, potentially rich with the United States Geological Survey estimated in 2009 that the Democratic Republic of the Congo (DRC) untapped mineral deposits to $\$ 24$ trillion, including the world's largest reserves of Coltan (essential element for phone manufacturer) and significant quantities of the world's cobalt (essential element for electric car manufacturers). Estimation shows that the DRC possesses 1 million tons of lithium resources. In addition to Eastern Congo large Coltan, Gold, Diamond, thin, lithium or natural gas deposit, it has in continuity with other provinces the world largest forest (equator forest), only after amazon, and has a largely untapped farmlands with the arable land potential to feed one billion people, nearly the rest of Africa (World Bank 2020). Yet, according to the same source, disputes over these resources drive the conflicts, and rebel groups seek to control them to fund their own campaigns (Counsel of Foreign Relations 2020). Furthermore, the eastern region of DRC has been grappling with an Ebola outbreak especially in the North Kivu and Ituri provinces since August 2018. According to the World Bank report (2020), the instability and insecurity that have faced the region has long hampered the country's Ebola response. As of June 13, 2019, 2084 cases (1990 confirmed and 94 probable cases) had been identified by the World Health Organization. Of the number of cases, 1405 have died among which women (57\%) and children (29\%). Figure 3 shows the areas

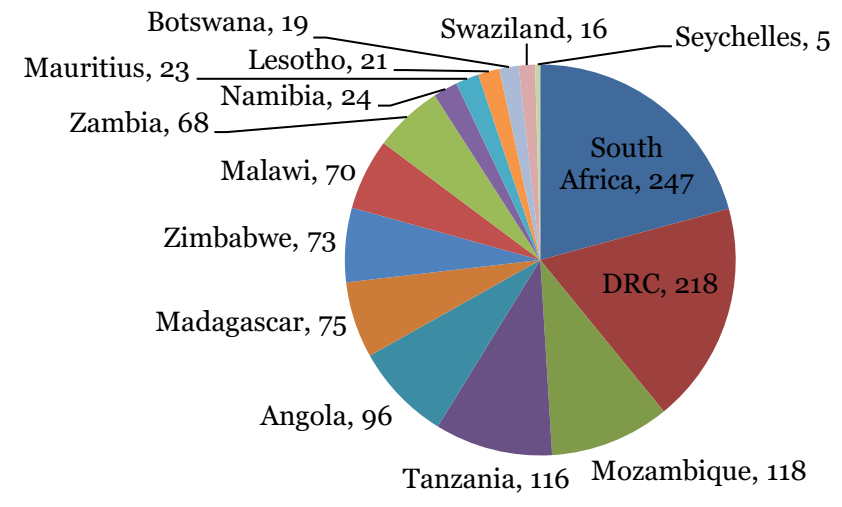

Fig. 2 Total SADC man-made and natural disaster proportion

affected by Ebola in the Eastern part of Congo. While Table 2 shows the type of disasters that have affected each province in the region.

For Man-made disasters, conflicts have affected all three provinces in the Eastern Congo. With DRC central government inability to resolve ethnics and regional differences, top to that the systematic collapse of the state footprint into the regional key infrastructures and mining facilities, the Counsel of Foreign Affairs (2019) believes that many in the eastern Congo felt abandoned and left to deal with all those conflicts for themselves, both economically and militarily. The resulting proliferation of militias has become deeply intertwined with local economies (Counsel of Foreign Affairs 2019). These conflicts led at some point several key Coltan, gold and other important mines falling under the control of rebel groups. Figure 4 has listed the key rebel groups fueling conflicts in the Eastern Congo.

Informal, or "artisanal," mining, as shown in Table 2 constitutes as much as a one-fifth of the country's economic output and offering employment to nearly two million of people in eastern Congo according to the United Nations estimates (2018), also contributing up to $22 \%$ of the Congo GDP (International Monetary Fund 2017). Artisanal mining trade is also a worthy catalyst for conflicts as it serves as source of income for arm rebel groups and corrupt government officials alike, as well as for illegal
Fig. 1 DRC man-made and natural number killed and total affected

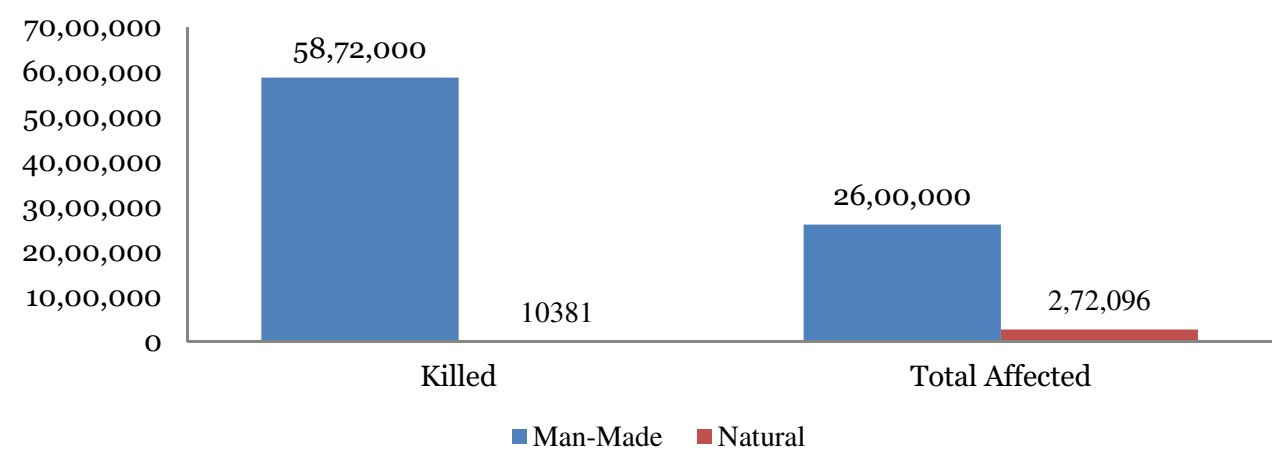


Fig. 3 Areas affected threaten by Ebola Epidemic in the Eastern Congo (OCHA RDC 2019)

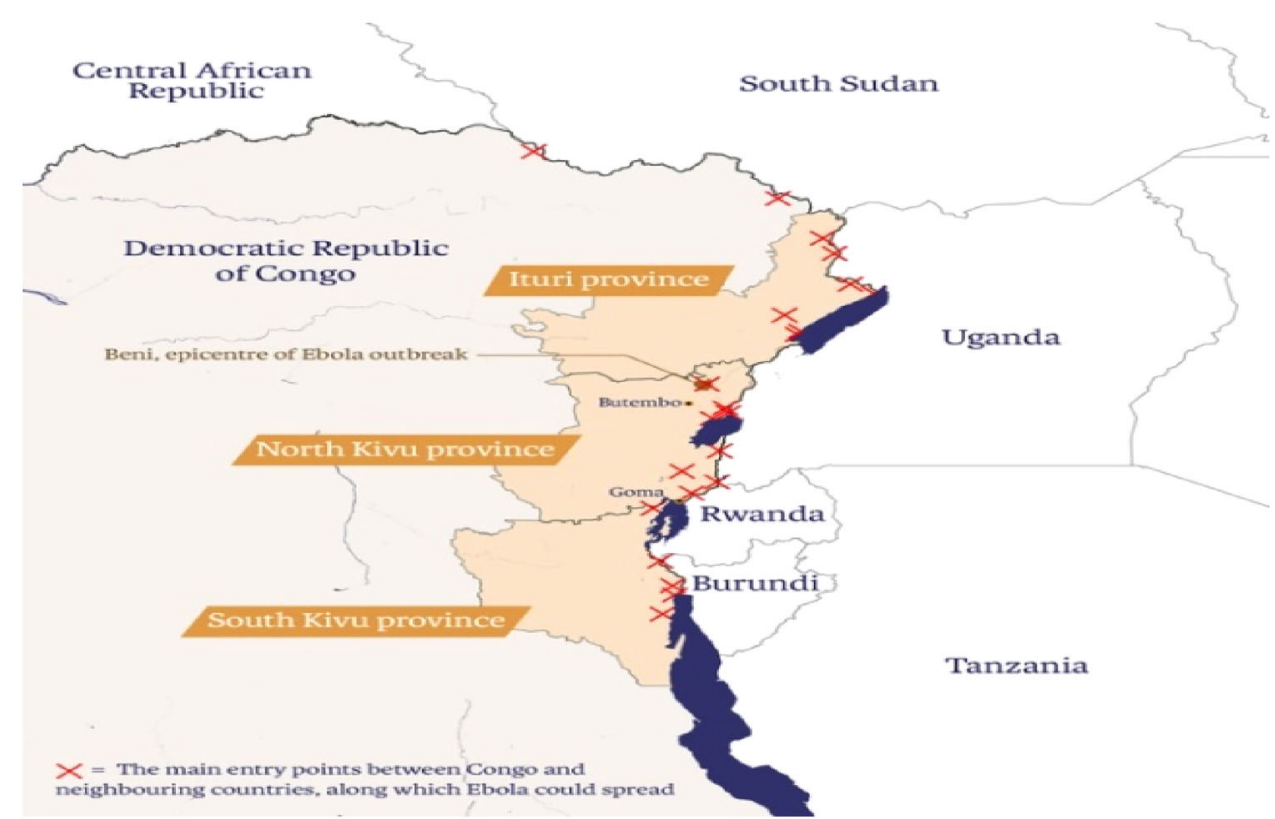

Table 2 Type of natural and man-disaster affecting the three provinces in the Eastern Congo (EM-DAT 2016; World Vision 2018)

\begin{tabular}{lll}
\hline Study provinces & \multicolumn{2}{l}{ Type of disaster } \\
\cline { 2 - 3 } & Natural disaster & Man-made disaster \\
\hline DRC & & \\
South Kivu province & Gas flaring, floods, landslides, epidemics and pandemics & Artisanal and small-scale mining, arms conflicts \\
North Kivu province & Gas flaring, deforestation, volcanoes, epidemics and pandemics & Artisanal and small-scale mining, arms conflicts \\
Ituri province & Landslides, floods, deforestation, epidemics and pandemics & Artisanal and small-scale mining, arms conflicts \\
\hline
\end{tabular}

traders operating from neighboring countries directly or through local armed allies (Counsel of Foreign Relations 2020).

Many humanitarian organizations are actively operating in the Eastern region of the DR Congo, providing people with much needed humanitarian reliefs. These abilities to respond timeously have however been hampered by the risk of being caught in the crossfire as a result of the unpredictable nature of those conflicts. Other challenges faced by relief organizations include the absence of proper planning (considering the natural and man-made disasters affecting the region), lack of communication and co-ordination challenges and the inaccessibility of regions and villages affected (Mpita et al. 2016, RDC Humanitaire 2020; Oxfam International 2014; Kembro 2012).

\subsection{Pre-positioning relief supply in DRC}

For Hale and Moberg (2005), the storage of emergency supplies, equipment, and vital documents that is needed in times of crisis are a critical component of disaster management planning in supply chains. To achieve that, Turnquist and Rowls (2009) believe that preparing the region is by prepositioning supplies at strategic locations to ensure that reliefs are safe and available when needed. With the all Eastern side of the DRC being exposed to risk of potential new disasters, it worth developing new prepositioned relief supplies in those three affected provinces, taking into account the accessibility to the warehouses, the security of personnel's managing those warehouses and the goods, the locations of those facilities ensuring that they are as close as possible and as accessible as possible to the victims. Other key element to make sure of is that the warehouses are holding adequate quantity.

\subsection{Humanitarian logistics and facility location problem in humanitarian context}

Disaster occurs unexpectedly, which result to a sudden higher demand for supplies but only in a short response time (Mpita et al. 2016). To address these crisis, Tomasini and Van Wassenhove (2009) suggested propositioning the 


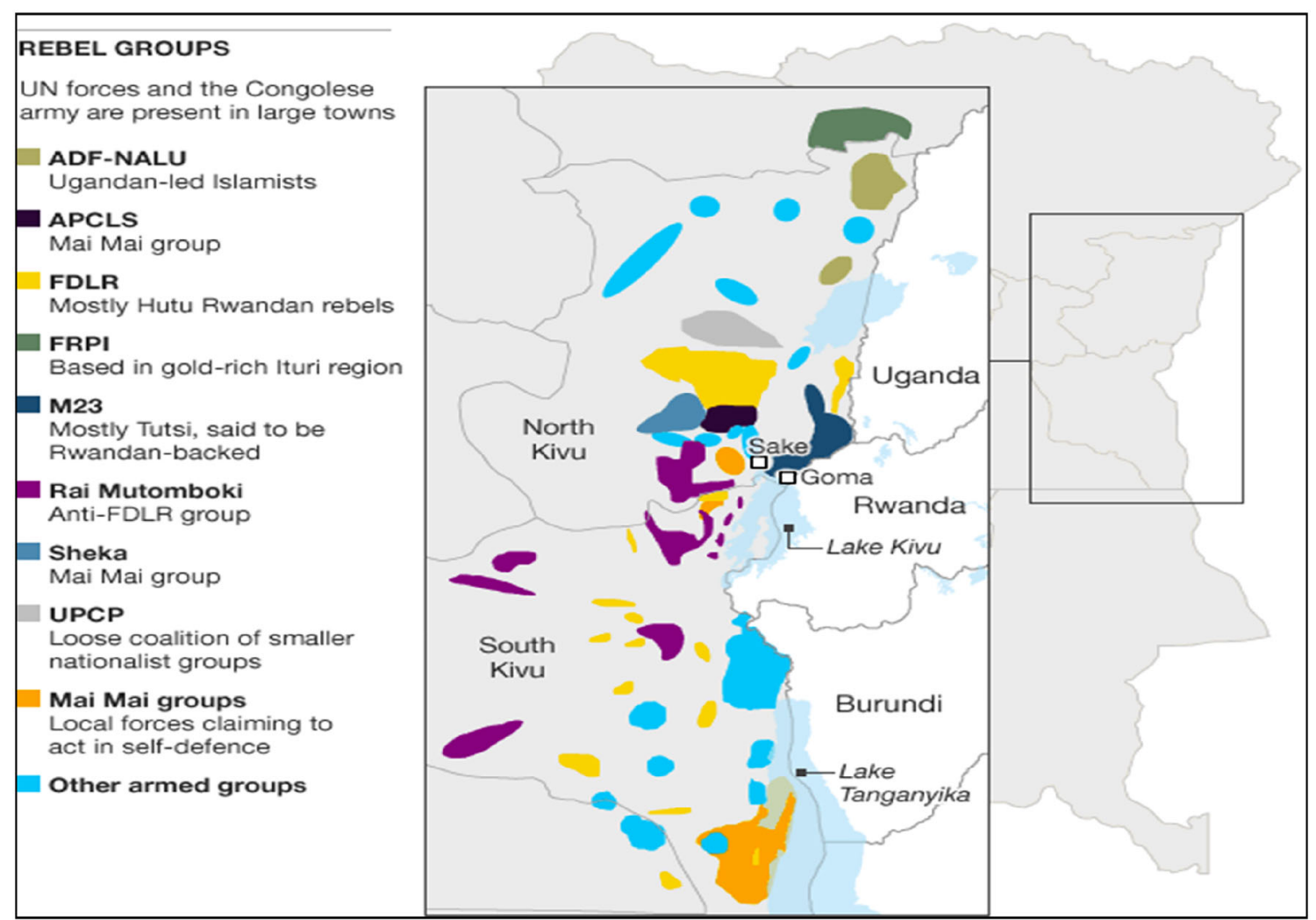

Fig. 4 Rebel groups operating in the Eastern Congo

right kind of supplies, in the right quantities at the right place and time for future need. Prepositioning location facility has therefore emerged in the recent years as one of the most effective tools in humanitarian disaster planning. For the preposition relief supplies efforts to be successful, Balcik and Beamon (2008) argue on the need for the location planning for warehouses as a critical step in the disaster management process. Kunz et al. (2013) further emphasize on the key role disaster preparedness plays in reducing the impact of disasters worldwide, and prepositioning is a preparedness method used especially by countries with natural or man-made disasters history. In the last decades, a lot of research has looked in prepositioning in the context of disaster relief or emergency response. Tomasini and Van Wassenhove (2009) believe that applying prepositioning method lowers procurement costs and increases the speed of relief supplies to disaster areas by allocating the potentially needed goods closer to demands points. Most of reviewed literatures dealing with the prepositioning of disaster relief are more focused on a strategic decision level such decision related to finding the best locations for facilities as well as determining the quantity of stock supplies (Root et al. 2012). For facility locations planning, Caunhye et al. (2011) and many other authors used Mixed-Integer programmes with binary location variables for locating potential facilities able to preposition relief supplies. Duran et al. (2011) for instance used a mixed-integer programming formulation to calculate the optimal locations and stocking relief supplies. Duran et al. (2011) model minimizes the average response time for transporting the relief supplies from selected prepositioned warehouses or global supplies to regional demand locations. And based on the disaster scenarios faced, the best decision will be selected.

Other key contributors to the topic such as Campbell and Jones (2011) and Balcik and Beamon (2008) used mathematical models to quantify and locate potential distribution center (DC) to be part of emergency facilities network, also inventory management at the established facilities. Kim et al. (2011) introduced a quantitative approach to multiobjectives prepositioning by maximizing the total expected relief demand of a potential vulnerable disaster areas. This approach assists distribution centers through four objectives: (1) maximum response time limit, (2) budget availability, (3) multiple item types, and (4) capacity restrictions. Furthermore, Van Wyk et al. (2013) presented a multi-objective approach to prepositioning of the relief supplies in Somalia. To solve the model, these authors above used pre-emptive optimization model which improves one objective function at a time without compromising the others. This approach has been found useful for multiple conflicting objectives. 
Nahleh et al. (2013) solved another multi-objective facility location problem in emergency logistics by integrating business 'best practices' such as just-in-time, addressing therefore facility location problem in terms of material flow. Nahleh et al. (2013) findings also include an escalation of orders from local DC to regional, continental as far as the main warehouses, to replenish the initial relief items that were distributed to affected area. According to Timperio et al. (2017), this model by Nahleh et al. (2013) looks at facility location problem in emergency logistics more from a global perspective, rather than last mile (in country) logistics. In Nahleh et al. (2013) model, the country affected by a disaster requests support from the nearest regional prepositioned DC which, while assisting beneficiaries, will place relief items restock orders to continent warehouse. The continental warehouse, following the similar pattern, will place an order to the main warehouses (Nahleh et al. 2013).

Multi-criteria decision making (MCDM) is both a quantitative and qualitative way of optimizing the pre-positioning locations facility. The MCDM was first represented in the perspective of facility location problem by designing a framework and ranking them in terms of importance by Roh et al. (2013) contrasting Hale and Moberg (2005) approach that focused on the pre-positioning of strategic stockpiles from the perspective of cost efficiency. Roh et al. (2013) proposes a secure falicity selection process, balancing the "operational effectiveness and cost efficiency through the identification of the minimum number and possible locations of offsite storage facilities" (Hale and Moberg 2005).

Degener et al. (2013) uses of multi-criteria decision making in a small-scale to a real-life scenario in Bangladesh helped bring more transparency in results. Recently, MCDM was employed by Timperio et al. (2017) to provide a decision support framework for facility locations identification with the purpose of addressing network design in Indonesia disaster relief supply chains. Among the researches listed and described above, none of them captures the technicalities of a real-life case as such covered by Timperio et al. (2017), particularly from the perspective of multi-criteria decision making. Most literature reviews that deal with facility location problem through optimization techniques with the support of quantitative data. Timperio et al. (2017) approach, used in this research, is an interdisciplinary approach that integrated both quantitative and qualitative evidence, and providing a full-bodied and adjustable methodology when replicated in other contexts. The decision support used in this study integrates quantitative and qualitative data and applied in linear programming model.

\section{Research methodology}

In the study methodology, we describe the key logistical challenges affecting facility location and transportation decisions. Then this section will define the facility location problem, and present the model formulation.

\subsection{Model description}

Relief delivery system involves a large number of players and stakeholders (beneficiaries, host governments, local and international relief organizations, donors, etc.) and operates in highly unpredictable, dynamic and disordered environments (Balcik and Beamon 2008). Each and every stakeholder ensures that the relief operations are done quickly and effectively. Successful disaster response activities during or in the aftermath of a conflict take into account a wide range of factors among which uncertainties, variability in the relief types, the relief sources or even the warehouses to store the reliefs just acquired. Unlike it is accustom in a commercial supply chains where logistic operations are more consistent therefore planned in advance of demand, most logistical decisions in the humanitarian relief chain however are made within shorter time frames (Balcik and Beamon 2008). To deal with highperformance disaster response, long-term supply chain planning is required for facility location as well as the stock pre-positioning decisions. Disaster happens suddenly, and once it has, demands for large amounts of goods of different variety of supplies suddenly occurs. Beamon (2004) identified in Fig. 5 four main phases of disaster relief representing the flow of resources to the affected areas: (1) assessment: critical process because it demonstrates the ability of a relief organization to identify what minimal resources are required, then (2) deployment mobilizes the resources required to meet the needs, (3) sustainment: operations are continued for a period of time, and (4) reconfiguration: operations are reduced, then brought to an end.

Each phase listed in Fig. 5 varies depending on the disaster characteristics and the region level of preparedness for disaster. However, the speed is essential at every relief operations phase in order for them to live up to their expectation of saving lives.

\subsection{Data gathering}

Besides literatures review, the study has utilized various agencies and departments active in climate variability monitory and response. Although articles and past reviewed papers served the research a great deal; Governmental, non-governmental and intergovernmental 
Fig. 5 Relief mission life cycle. Source: Beamon (2004)

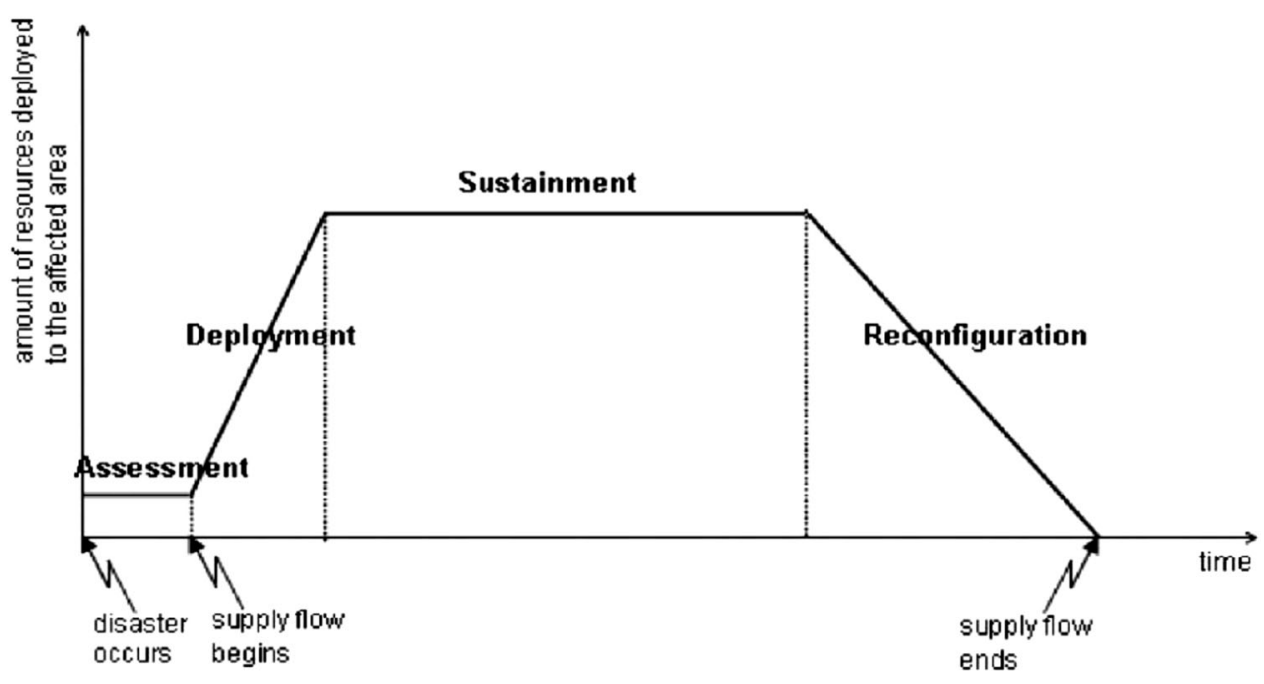

organizations assisted in identifying the history of conflicts in the Ituri, North and South Kivu. The following agency databases were utilized for this research: EM-DAT, United Nations Office for the Coordination of Humanitarian Affairs (UNOCHA), DRC Emergency Agency, RDC Humanitaire, Relief Web International, World Bank RDC, and World Health Organization, Counsel of Foreign Relations, CARE, OXFAM, USAID, FAO/WFP, NOAA, DRC HF, Public Health Emergency of International Concern (PHEIC) and other collaborating institutions.

\subsubsection{Identified conflict areas and storage facility locations}

The potential conflict areas listed in the Table 3 were collected from various sources operating in the region. The table also identified the Total number of conflicts in those areas and the probability of conflicts in cities in North Kivu, South Kivu and Ituri. Table 3 also shows that even areas with small population size were not spared from conflicts. The facility locations should ideally be located into conflicts areas with relatively higher population size, but with lower probability of conflicts. The higher population size cities in DRC often possess more structured administrative systems, relatively fair infrastructures and
Table 3 Probability of conflict in identified conflict areas

\begin{tabular}{llrl}
\hline Provinces & Conflits area & Total number of conflicts & Probability of conflict \\
\hline North Kivu & Masisi & 31 & 0.136 \\
& Beni & 30 & 0.132 \\
& Lubero & 23 & 0.101 \\
& Rutshuru & 16 & 0.070 \\
& Walikale & 16 & 0.070 \\
& Butembo & 10 & 0.044 \\
South Kivu & 7 & 0.031 \\
& Goma & 15 & 0.075 \\
& Uvira & 15 & 0.066 \\
& Shabunda & 10 & 0.053 \\
& Fizi & 9 & 0.039 \\
& Kalehe & 7 & 0.031 \\
Mwenga & 3 & 0.026 \\
Kabare & 1 & 0.018 \\
& Walungu & 10 & 0.044 \\
& Djugu & 6 & 0.026 \\
& Irumu & 4 & 0.018 \\
& Mahagi & 3 & 0.013 \\
& Mambasa & 2 & 0.009 \\
\hline
\end{tabular}


transportation systems, deployed army and police units ready to defend the city against any attack. Also, to be added are hospitals, schools, churches, with all those offering humanitarian personnel viable option for facility locations. The lower probability of conflicts rate is equally important because it limits the impending risks on humanitarian personnel and reliefs. Table 3 summarizes the resulting list of potential storage locations.

As explained, the candidate locations for distribution centers as shown in Table 3 are the region with relatively higher population size while lower probability of conflicts from each of the three provinces. The locations of the 7 candidate sites for distributions centers in North Kivu, 8 candidate sites for distributions centers in South Kivu and 5 candidate sites for distributions centers in Ituri province. According to Table 4, Goma and Butembo are respectively the most populated cities with the best probability of conflict per population size in the North Kivu province. Bukavu and Mwenga are respectively the most populated cities with the best probability of conflict per population size in the South Kivu province. Mambasa and Bunia are respectively the most populated cities with the best probability of conflict per population size in the South Kivu province.

\subsubsection{Transportation and response times}

The Congolese government, the regional authorities and their partners use the capital cities of each province as the main distribution center (Bunia for ituri, Goma for North Kivu and Bukavu for South Kivu). And from those towns and towns from neighboring provinces, the humanitarian reliefs are transported to distribution centers located at various territories by road, helicopters or planes. For instance, the WFP owns a fleet of 18 military trucks in the both Kivu region, each with the capacity of seven metrictonnes (WFP 2012). The UN mission in the Congo (MONUSCO) offers a great deal of assistance with it fleets of MI-8 helicopters and cargo planes ready to intervene especially in case of poor road conditions or bridges damage. It is worth noting the risk of ambushes from antigovernment forces that humanitarian personnel's and goods are faced with especially on the poorly maintained roads where the average speed is estimated at $40 \mathrm{~km} / \mathrm{h}$.

\subsubsection{Areas stock pre-positioning}

Previous researches such as Mpita et al (2016), Reliefweb or RDC Humanitaire (2020) have detailed the number of displaced and various other challenges and reliefs expectation are needed. Mpita et al. (2016) use those data in the

Table 4 Potential locations of facilities

\begin{tabular}{|c|c|c|c|c|}
\hline Provinces & Conflits area & Population size & Total number of conflicts & Probability of conflict per population size \\
\hline \multirow[t]{7}{*}{ North Kivu } & Goma & $2,000,000$ & 7 & 0.000004 \\
\hline & Butembo & $1,154,621$ & 10 & 0.000009 \\
\hline & Rutshuru & 250,000 & 16 & 0.000064 \\
\hline & Walikale & 201,000 & 16 & 0.000080 \\
\hline & Beni & 231,952 & 30 & 0.000129 \\
\hline & Lubero & 57,356 & 23 & 0.000401 \\
\hline & Masisi & 6502 & 31 & 0.004768 \\
\hline \multirow[t]{8}{*}{ South Kivu } & Bukavu & 870,954 & 5 & 0.000006 \\
\hline & Mwenga & 806,940 & 7 & 0.000009 \\
\hline & Walungu & 85,000 & 1 & 0.000012 \\
\hline & Shabunda & 923,000 & 15 & 0.000016 \\
\hline & Kalehe & 462,465 & 9 & 0.000019 \\
\hline & Uvira & 378,736 & 15 & 0.000040 \\
\hline & Kabare & 37,034 & 3 & 0.000081 \\
\hline & Fizi & 30,000 & 10 & 0.000333 \\
\hline \multirow[t]{5}{*}{ Ituri } & Mambasa & 249,073 & 3 & 0.000012 \\
\hline & Irumu & 366,126 & 6 & 0.000016 \\
\hline & Aru & 94,267 & 2 & 0.000021 \\
\hline & Mahagi & 67,954 & 4 & 0.000059 \\
\hline & Djugu & 28,061 & 10 & 0.000356 \\
\hline
\end{tabular}


development of a model that integrates potential facility locations, multiple relief items, response times, and capacity restrictions while maximizing the proportion of demand satisfied by the pre-positioned relief supplies. However, in order to successfully pre-positioned stocks in regions with the history of arm conflicts, key considerations need to be taken into accounts. Among them are: (1) identification of best facility locations in each district, (2) available infrastructures and road conditions to reach those facilities, and finally (3) ensuring that the Transportation time and cost from main DC (chief town) to the district DC in minimized

To achieve this research, aim of stock pre-positioning, certain assumptions need to be raised:

- The choice of transportation modes to affected districts are based by many factors including the infrastructures, road conditions, the presence of administrative offices as well as the safety of goods and staffs. For instance, Helicopter mode of transportation offers safe time and protects goods and personnel from attacks that could occur by road.

- Trucks, fuels and labor are available all along the supply chain from the main distribution center to the District DC.

- The main DC has sufficient humanitarian reliefs as stated in Table 5 to supply to all affected districts in Ituri, North Kivu and South Kivu.
1. Identification of facility locations

Tables 5 and 6 have listed districts with high conflicts rates. Among the vulnerable areas the three provinces being study, towns or cities of higher population rates are prime candidates for distribution centers (DC). DC (warehouses) needs to be located in area with a relatively stronger security organization with the national police stations and army bases as well as the regional agencies in charge of various services. Other key service includes hospital, clinics and commercial places.

2. Available infrastructures and road conditions

The relief supplies are transported from DC to affected areas using all available transportation modes including trucks, airplanes, helicopters even boats depending on the road conditions, availability, the urgency as well as the quantity and the cost. Many international organizations such as the WFP as well as the government organization such as the military logistics own fleets of trucks, Helicopters and other relevant transportation modes are found in the region available for the mission. Mpita et al. (2016) mentioned the availability of MI-8 Helicopters for relief supplies to remote areas of Shabunda, where roads and other infrastructures are nearly inexistent. In order to determine the best transportation decision for each affected territory in the region, Table 6 set up a scale (good, fair, bad and critical) of evaluation of the infrastructures in the

Table 5 Listed the towns or cities per district with high population, connectivity, warehouses, infrastructures and administrative systems

\begin{tabular}{|c|c|c|c|c|c|}
\hline Provinces & Conflicts districts & Population size & Potential cities & Populated city & Population size \\
\hline \multirow[t]{6}{*}{ North Kivu } & Goma & $2,000,000$ & Goma, Karisimbi & Goma & 941,456 \\
\hline & Rutshuru & $1,606,357$ & Rutshuru, Bwito, Bwisha, Kiwanja & Rutshuru & 250,000 \\
\hline & Walikale & 987,265 & Walikale, Bakano, Wanianga & Walikale & 16,147 \\
\hline & Beni & 916,181 & Beni, Beu, Bungulu, Mulekera, Ruwenzori & Beni & 129,163 \\
\hline & Lubero & $1,063,586$ & Lubero, Butembo, & Butembo & 744,838 \\
\hline & Masisi & 711,075 & Masisi, Katoyi, Bahunde, Osso Banyungu & Masisi & 18,708 \\
\hline \multirow[t]{8}{*}{ South Kivu } & Bukavu & 870,954 & Bukavu & Bukavu & 415,521 \\
\hline & Mwenga & 786,961 & Mwenga, Wamuzima, Kamituga, Basile, Itombwe & Mwenga & 424,000 \\
\hline & Walungu & 720,780 & Walungu, Ngweshe, Kaziba & Walungu & 68,857 \\
\hline & Shabunda & 925,733 & Shabunda, Bakisi, Wakabango & Shabunda & 30,946 \\
\hline & Kalehe & 815,326 & Biloho, Bahavu, Bunyakiri & & \\
\hline & Uvira & $1,181,207$ & Uvira, Bafulero, Bariva, Plaine of Ruzizi & Uvira & 378,736 \\
\hline & Kabare & 780,616 & Kabare, Ninja & Kabare & 37,034 \\
\hline & Fizi & $1,022,044$ & Fizi, Mutambala, Lulenge, Ngandja & Fizi & 30,000 \\
\hline \multirow[t]{5}{*}{ Ituri } & Mambasa & 746,287 & Mambasa, Madidi, Nia Nia, Koko & Mambasa & 249,073 \\
\hline & Irumu & $1,288,343$ & Bunia, Nyankunde & Bunia & 366,126 \\
\hline & Aru & $1,502,726$ & Aru, Ariwara, Kakwa & Aru & 94,267 \\
\hline & Mahagi & $2,636,284$ & Mahagi, Reti, Walendu Watsi & Mahagi & 67,954 \\
\hline & Djugu & $2,824,047$ & Djugu, Mongbwalu, Walendu, Bahema, Mabisa & Djugu & 28,061 \\
\hline
\end{tabular}


Table 6 Evaluation scale of infrastructures, road conditions, administrative offices, security and health

\begin{tabular}{|c|c|c|c|c|c|}
\hline & Infrastructures & Road conditions & Administrative offices & Security & Health \\
\hline Good & $\begin{array}{l}\text { Road, airport, } \\
\text { marine, train }\end{array}$ & $\begin{array}{l}\text { Average speed of } \\
100 \mathrm{~km} / \mathrm{h}\end{array}$ & $\begin{array}{l}\text { Al necessary government } \\
\text { offices operating on sites }\end{array}$ & $\begin{array}{l}\text { Well equiped police } \\
\text { stations, army bases }\end{array}$ & $\begin{array}{l}\text { Well equiped health facilities with } \\
\text { qualified personnel }\end{array}$ \\
\hline Fair & Road, airport, & $\begin{array}{l}\text { Average speed of } \\
40-60 \mathrm{~km} / \mathrm{h}\end{array}$ & $\begin{array}{l}\text { Just enough government } \\
\text { offices are operational }\end{array}$ & $\begin{array}{l}\text { Barely equiped police } \\
\text { stations, army bases }\end{array}$ & $\begin{array}{l}\text { Barely equiped health facilities } \\
\text { with limit qualified personnel }\end{array}$ \\
\hline Bad & Airport & $\begin{array}{l}\text { Average speed of } \\
5-15 \mathrm{~km} / \mathrm{h}\end{array}$ & $\begin{array}{l}\text { Limited number of regional } \\
\text { offices operating on sites }\end{array}$ & $\begin{array}{l}\text { Poorly equiped police } \\
\text { stations, army bases }\end{array}$ & $\begin{array}{l}\text { Limited health facilities with no } \\
\text { qualified personnel }\end{array}$ \\
\hline Critical & None & $\begin{array}{l}\text { Broken roads and } \\
\text { bridges }\end{array}$ & $\begin{array}{l}\text { No regional offices operating } \\
\text { on sites }\end{array}$ & $\begin{array}{l}\text { No army bases, poor } \\
\text { security presence }\end{array}$ & No health facilities present \\
\hline
\end{tabular}

affected areas, the road conditions leading to the affected areas, the presence of administrative offices in the areas affected, the security of goods and personnel during the travelling, the storage and distribution. Finally, the evaluation also determines the scale of the presence of health care facilities, staffs, medication and equipment to the population of the affected area.

From the evaluation scale framework listed in Table 6, the next Table 7 evaluates the state of each of those relief transportations preconditions province by province. The outcome shows the advance destruction states of some regional roads leading to affected areas as well as some security challenges.

\section{Transportation time and cost}

From the evaluation, decisions are made on which transportation modes to be used in each area, taking into account the security of goods and staffs. Poor road conditions and the availability of transportation modes are one of the major issues often faced by relief organizers. Other minor, yet significant hurdles encountered include possible disruptions caused by conflicts. After key transportation factors are established, in order to estimate the demand and the supply quantity of reliefs to candidate cities, Table 8 below estimates the distance from the Main DC to those candidates DC from affected areas:

\section{a. Constraint conditions}

Among the assumptions, one is that relief supplies donated from disaster agencies are available at each of the three Distribution Center (Goma, Bukavu and Bunia). From the Distribution Centres, supplies are sent to prepositioned hot spot areas in each province. The study also assumed that trucks, cargo planes, helicopters and personnel are available and ready for the delivery when needed. Each potential hot spot areas are assumed to possess warehouses capable of storing relief supplies. The supply and demand quantities for the affected areas were determined based on historical data and the amount of vulnerable population size.

From Table 7, the following are areas are listed as vulnerable areas for conflicts and candidate relief destination: South Kivu Province (Bukavu, Mwenga, Walungu, Kahele, Shabunda, Uvira, Kabare and Fizi), North Kivu Province (Goma, Beni, Butembo, Rutshuru, Walikale and Masisi), and Ituri Province (Bunia, Mambasa, Aru, Mongbwalu, and Mahagi). Each province chief town is the main Warehouse [Bukavu in South Kivu (Wl), Goma in North Kivu (W2) and Bunia in Ituri (W3)] or Distribution Centre (DC).

The demand for each province is represented respectively by the following symbols: $\boldsymbol{W d} \boldsymbol{I}\left(\mathrm{D} s_{1}, \mathrm{D} s_{2}, \mathrm{D} s_{3}, \mathrm{D} s_{4}\right.$, $\mathrm{D} s_{5}, \mathrm{D} s_{6}, \mathrm{D} s_{7}$ and $\left.\mathrm{D} s_{8}\right), \boldsymbol{W} \boldsymbol{d}\left(\mathrm{D} n_{1}, \mathrm{D} n_{2}, \mathrm{D} n_{3}, \mathrm{D} n_{4}, \mathrm{D} n_{5}\right.$ and $\left.\mathrm{D} n_{6}\right)$ and $\boldsymbol{W d}\left(\mathrm{D} i_{1}, \mathrm{D} i_{2}, \mathrm{D} i_{3}, \mathrm{D} i_{4}\right.$ and $\left.\mathrm{D} i_{5}\right)$. The supply for each province is represented respectively by the following symbols: Ws1 $\left(\mathrm{S}_{1}, \mathrm{Ss}_{2}, \mathrm{~S} s_{3}, \mathrm{~S} s_{4}, \mathrm{~S} s_{5}, \mathrm{D} s_{6}, \mathrm{Ss}_{7}\right.$ and $\left.\mathrm{S} s_{8}\right)$, $\boldsymbol{W} \mathbf{2}\left(\mathrm{S} n_{1}, \mathrm{~S} n_{2}, \mathrm{~S} n_{3}, \mathrm{~S} n_{4}, \mathrm{~S} n_{5}\right.$ and $\left.\mathrm{S} n_{6}\right)$ and $\boldsymbol{W} \mathbf{s}\left(\mathrm{Si}_{1}, \mathrm{~S} i_{2}\right.$, $\mathrm{Si}_{3}, \mathrm{Si}_{4}$ and $\mathrm{Si}_{5}$ ). Each variable relates to those following areas: Bukavu (W1, Ds1, $\mathrm{S} s_{1}$ ), Mwenga (W1, Ds $s_{2}, \mathrm{Ss}_{2}$ ), Walungu (W1, D $s_{3}, \mathrm{~S} s_{3}$ ), Kahele (W1, Ds $s_{4}, \mathrm{~S} s_{4}$ ), Shabunda $\left(\mathrm{W} 1, \mathrm{D} s_{5}, \mathrm{~S} s_{5}\right.$ ), Uvira (W1, D $s_{6}, \mathrm{~S} s_{6}$ ), Kabare (W1, D $s_{7}$, $S s_{7}$ ), Fizi (W1, D $s_{8}, \mathrm{~S} s_{8}$ ), Goma (W2, D $n_{1}, \mathrm{~S} n_{1}$ ), Beni (W2, $\mathrm{D} n_{2}, \mathrm{~S} n_{2}$ ), Butembo (W2, D $n_{3}, \mathrm{~S} n_{3}$ ), Rutshuru (W2, D $n_{4}$, $\mathrm{S} n_{4}$ ), Walikale (W2, $\mathrm{D} n_{5}, \mathrm{~S} n_{5}$ ), Masisi (W2, $\mathrm{D} n_{6}, \mathrm{~S} n_{6}$ ), Bunia (W3, Di $i_{1}, \mathrm{Si}_{1}$ ), Mambasa (W3, $\mathrm{D} i_{2}, \mathrm{~S} i_{2}$ ), Aru (W3, $\mathrm{D} i_{3}, \mathrm{Si}_{3}$ ), Mongbwalu (W3, $\left.\mathrm{D} i_{4}, \mathrm{Si}_{4}\right)$ and Mahagi (W3, D $i_{5}$, $S i_{5}$ ). Table 9 below assumes the demand and supply quantity for areas based on the population size and the estimated displaced population.

In order to optimize the disaster supply, the Transportation Time must be reduced while the Cost must be kept minimal. By reducing the delivery time, the number of warehouses readiness and victim's survival are increased. The Table 10 below give full details on the average transportation time $\mathrm{C}_{\mathrm{ij}}^{2}(\mathrm{~h} /$ piece $)$ and the average transportation cost $C_{i j}^{1}$ (US Dollar/piece) within Eastern DRC. 
Table 7 Province by province evaluation of infrastructures, road conditions, administrative offices, security and health

\begin{tabular}{|c|c|c|c|c|c|c|c|c|}
\hline Province & $\begin{array}{l}\text { Conflicts } \\
\text { area }\end{array}$ & Town & $\begin{array}{l}\text { Population } \\
\text { size }\end{array}$ & Infrastructures & $\begin{array}{l}\text { Road } \\
\text { conditions }\end{array}$ & $\begin{array}{l}\text { Administrative } \\
\text { offices }\end{array}$ & Security & Health \\
\hline \multirow[t]{8}{*}{$\begin{array}{l}\text { South } \\
\text { Kivu }\end{array}$} & Bukavu & Bukavu & 870,954 & $\begin{array}{l}\text { Road, airport, } \\
\text { marine }\end{array}$ & Fair & Good & Good & Good \\
\hline & Mwenga & & 806,940 & $\begin{array}{l}\text { Road, marine, } \\
\text { airport }\end{array}$ & $\mathrm{Bad}$ & Fair & Fair & Bad \\
\hline & Walungu & Walungu & 85,000 & $\begin{array}{l}\text { Road, airport, } \\
\text { marine }\end{array}$ & Fair & Fair & Fair & Fair \\
\hline & Kalehe & Kahele & 462,465 & $\begin{array}{l}\text { Road, airport, } \\
\text { marine }\end{array}$ & Fair & Fair & Fair & Fair \\
\hline & Shabunda & Shbunda & 923,000 & $\begin{array}{l}\text { Road, airport, } \\
\text { marine }\end{array}$ & Critical & $\mathrm{Bad}$ & Fair & $\mathrm{Bad}$ \\
\hline & Uvira & Uvira & 378,736 & Road, marine & Fair & Fair & $\mathrm{Bad}$ & Fair \\
\hline & Kabare & Kabare & 37,034 & $\begin{array}{l}\text { Road, airport, } \\
\text { marine }\end{array}$ & Fair & Fair & Fair & Fair \\
\hline & Fizi & Fizi & 30,000 & $\begin{array}{l}\text { Road, airport, } \\
\text { marine }\end{array}$ & Bad & $\mathrm{Bad}$ & Critical & $\mathrm{Bad}$ \\
\hline \multirow[t]{6}{*}{$\begin{array}{l}\text { North } \\
\text { Kivu }\end{array}$} & Goma & Goma & $2,000,000$ & $\begin{array}{l}\text { Road, marine, } \\
\text { airport }\end{array}$ & Good & Good & Good & Good \\
\hline & Beni & Beni & 916,181 & Road and flights & Good & Fair & $\mathrm{Bad}$ & $\mathrm{Bad}$ \\
\hline & Lubero & Butembo & & & & Fair & $\mathrm{Bad}$ & $\mathrm{Bad}$ \\
\hline & Rutshuru & Rutshuru & & & & Fair & Bad & Fair \\
\hline & Walikale & Walikale & & & & Fair & Critical & $\mathrm{Bad}$ \\
\hline & Masisi & Masisi & 18,708 & Road and flights & Fair & Fair & Critical & $\mathrm{Bad}$ \\
\hline \multirow[t]{5}{*}{ Ituri } & Irumu & Bunia & 366,126 & $\begin{array}{l}\text { Road, airport, } \\
\text { marine }\end{array}$ & Fair & Fair & Fair & Fair \\
\hline & Mambasa & Mambasa & 249,073 & Road and flights & Bad & Fair & Bad & Fair \\
\hline & Aru & Aru & 94,267 & Road and flights & Fair & Fair & Fair & Fair \\
\hline & Djugu & Mongbwalu & 28,061 & $\begin{array}{l}\text { Road, airport, } \\
\text { marine }\end{array}$ & $\mathrm{Bad}$ & Critical & Critical & Critical \\
\hline & Mahagi & Mahagi & 67,954 & $\begin{array}{l}\text { Road, airport, } \\
\text { marine }\end{array}$ & Fair & Fair & $\mathrm{Bad}$ & $\mathrm{Bad}$ \\
\hline
\end{tabular}

Table 8 Province by province distance from chief town to the candidate distribution centre $(\mathrm{km})$

\begin{tabular}{|c|c|c|c|c|c|c|c|c|c|}
\hline \multirow{2}{*}{$\frac{\text { Provinces }}{\text { South Kivu }}$} & \multirow{2}{*}{$\frac{\text { Main DC }}{\text { Bukavu }}$} & \multicolumn{8}{|c|}{ Distribution centre candidates distance $(\mathrm{km})$} \\
\hline & & Bukavu & Mwenga & Walungu & Kahele & Shabunda & Uvira & Kabare & Fizi \\
\hline & Distance & 5 & 438 & 68 & 71 & 689 & 131 & 13 & 250 \\
\hline \multirow[t]{2}{*}{ North Kivu } & Goma & Goma & Beni & Butembo & Rutshuru & Walikale & Masisi & & \\
\hline & Distance & 6 & 334 & 285 & 71 & 413 & 78 & & \\
\hline \multirow[t]{2}{*}{ Ituri } & Bunia & Irumu & Mambasa & Aru & Mongbwalu & Mahagi & & & \\
\hline & Distance & 61 & 173 & 240 & 175 & 159 & & & \\
\hline
\end{tabular}

To be noted that the travelling time by road in the Eastern part of DRC is estimated at $40 \mathrm{~km} / \mathrm{h}$.

Road transportation is generally cheaper in comparison to air transportation. The gap between those two modes of transportation is excessively large in the DRC region most likely due to the bad state of most roads in the country and the limited amount of well equipped, well ran airports and well-maintained planes and helicopters. Furthermore, 'Transportation of goods using trucks in the SADC region cost between US\$ 120 and US\$ 280 per tonne, while air 
Table 9 Demand quantities

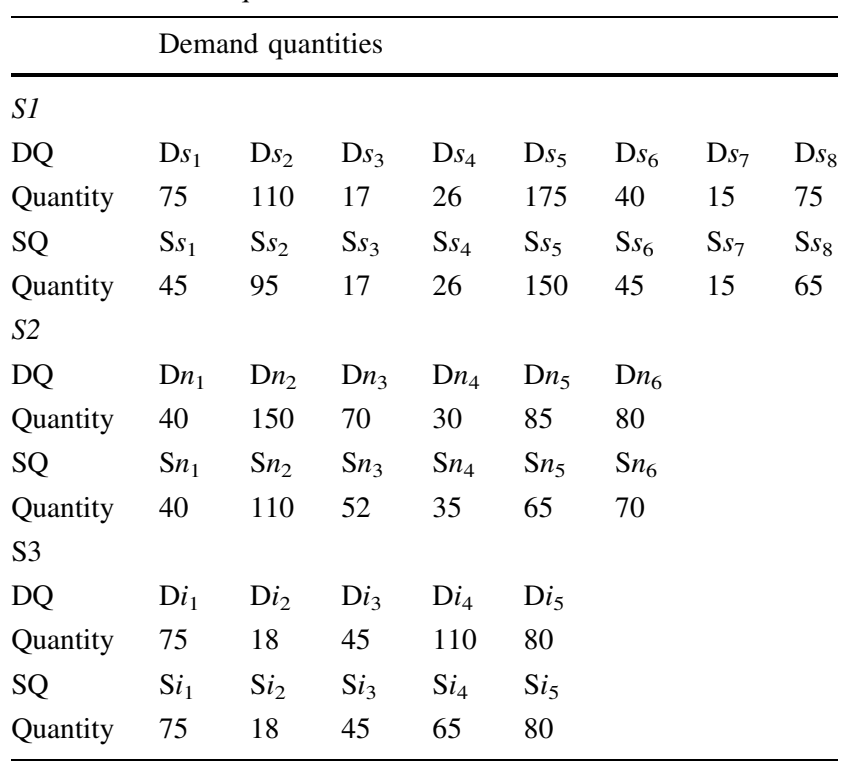

$S C$ supplier code, $S Q$ supply quantity (piece/day), $D Q$ demand quantity (piece/day)

transportation varies between US\$ 4000 and US\$ 6000 per tonne' (Ranganathan and Foster 2011). It needs to be noted that due to the advance degradation of many transportation infrastructures in DRC, the cost of transportation is a bit higher in comparison to other regional countries.

\section{Transportation problem}

Transportation problem was expressed by Prasad et al. (1993) in the mathematical language. With all consideration, a load of products is transported from each of $m$ sources to $n$ destinations. The sources are volunteers donating toward relief organization facilities, warehouses, or supply points, characterized by available capacities $a_{i}$, for $i=1,2,3,4,5,6,7, \ldots, m$. The destinations represent disaster consumption facilities, warehouses, or demand points, characterized by required levels of demand $b_{j}$, for $j=1,2,3,4,5,6,7, \ldots, n$. For the transportation time and cost to meet the minimum value simultaneously, the linear programming (LP) minimization $z_{q}$ needs to be formulated as follow:

$\min z_{q}=\sum_{i=1}^{m} \sum_{j=1}^{n} C_{i j}^{q} X_{i j}, \quad q=1,2$

Subject to:

$\sum_{j=1}^{n} X_{i j}=a_{i}, \quad i=1,2,3,4,5,6,7, \ldots, m$ $\sum_{i=1}^{m} X_{i j}=b_{j}, \quad j=1,2,3,4,5,6,7, \ldots, n$

$X_{i j} \geq 0, \quad \forall i, j$

With $C_{i j}(\mathrm{t})$ as the unit cost of transportation from supply point $\mathrm{m} i(i=1,2, \ldots, m)$ to demand point $j(j=1,2, \ldots, n)$ when the duration allowed for the transportation is $t$ units and the destination quantities of each countries $q$ units. Now, setting $X_{i j}$ to be the variable denoting the amount transported from supply point $i$ to demand point $j$, let $a_{i}$ be the availability at source points $i$ and $b_{j}$ the demand at demand point $j$.

The transportation problem (TP) input data could be expressed as intervals instead of point values. According to Jimenez and Verdegay (1998), interval is needed when uncertainty exist in data problem which are often the case in a disaster response situation. And decision makers are more comfortable expressing it as intervals. In this exercise, Jimenez and Verdegay (1998) have considered the TP in which intervals appear only in the constraint set, i.e., in the supplies, demands capacities, by means of equality constraints. The formula could be interpreted as follow:

Minimize $\sum_{i=1}^{m} \sum_{j=1}^{n} C_{i j}^{q} X_{i j}, \quad q=1,2$

Subject to:

$\sum_{j=1}^{n} X_{i j}=A_{i}, \quad i=1,2,3,4,5,6,7, \ldots, m$

$\sum_{i=1}^{m} X_{i j}=B_{j}, \quad j=1,2,3,4,5,6,7, \ldots, n$

$X_{i j} \geq 0, \quad \forall i, j$

where $\quad A_{i}=\left[a_{i}^{1}, a_{i}^{2}\right], \quad=1,2,3,4,5,6,7, \ldots, m$, $B_{i}=\left[b_{i}^{1}, b_{i}^{2}\right], j=1,2,3,4,5,6,7, \ldots, n$ are intervals of possible values for the supplies, demands capacities, respectively, and relation $=j$ is formally defined as

$w={ }_{1}[a, b] \overline{\overline{d e f}} \exists z \in[a, b]: w=z$.

\section{Results and findings}

With the estimated demand and supply quantity, the estimated cost per tonnes for transportations and the estimated time and distances; the following decision scenarios were developed: 
Table 10 Average transportation time transportation cost and Average

\begin{tabular}{|c|c|c|c|c|c|c|c|c|c|}
\hline \multirow{4}{*}{$\begin{array}{l}\text { Supplier } \\
\text { code }\end{array}$} & \multicolumn{8}{|c|}{ Average transportation cost } & \\
\hline & \multicolumn{8}{|c|}{ (US dollar/piece) $C_{i j}^{1}$} & \\
\hline & \multicolumn{8}{|c|}{ 1. Air transportation: between US\$4000 to US\$ 6000} & \\
\hline & \multicolumn{8}{|c|}{ 2. Route transportation: between US\$ 120 to US\$ 280} & \\
\hline Ws1 & $\mathrm{S} s_{1}$ & $\mathrm{Ss}_{2}$ & $\mathrm{~S}_{3}$ & $\mathrm{~S}_{4}$ & $\mathrm{~S} s_{5}$ & $\mathrm{~S} s_{6}$ & $\mathrm{~S} s_{7}$ & $\mathrm{~S} s_{8}$ & \\
\hline \multirow[t]{3}{*}{ SOUTH KIVU } & 45 & 95 & 17 & 26 & 150 & 45 & 15 & 65 & $\mathrm{SQ}($ piece $) a_{i}$ \\
\hline & - & $\$ 5400$ & $\$ 4895$ & - & $\$ 5520$ & $\$ 4950$ & - & $\$ 5150$ & Air trans $C_{i j}^{1}$ \\
\hline & $\$ 145$ & $\$ 240$ & $\$ 190$ & $\$ 200$ & $\$ 275$ & $\$ 205$ & $\$ 150$ & $\$ 220$ & Road trans $C_{i j}^{1}$ \\
\hline Ws2 & $\mathrm{S} n_{1}$ & $\mathrm{~S} n_{2}$ & $\mathrm{~S}_{3}$ & $\mathrm{Sn}_{4}$ & $\mathrm{~S} n_{5}$ & $\mathrm{~S} n_{6}$ & & & \\
\hline \multirow[t]{3}{*}{ NORTH KIVU } & 40 & 110 & 52 & 35 & 65 & 70 & & & SQ (piece) $a_{i}$ \\
\hline & - & $\$ 4950$ & $\$ 4810$ & $\$ 4800$ & $5 \$ 250$ & $\$ 4960$ & & & Air trans $C_{i j}^{1}$ \\
\hline & $\$ 160$ & $\$ 210$ & $\$ 205$ & $\$ 225$ & $\$ 255$ & $\$ 230$ & & & Road trans $C_{i j}^{1}$ \\
\hline Ws3 & $\mathrm{S} i_{1}$ & $\mathrm{Si}_{2}$ & $\mathrm{Si}_{3}$ & $\mathrm{Si}_{4}$ & $\mathrm{~S} i_{5}$ & & & & \\
\hline \multirow[t]{5}{*}{ ITURI } & 75 & 18 & 45 & 65 & 80 & & & & $\mathrm{SQ}($ piece $) a_{i}$ \\
\hline & $\$ 4560$ & $\$ 5045$ & $\$ 5190$ & $\$ 4620$ & $\$ 5150$ & & & & Air trans $C_{i j}^{1}$ \\
\hline & $\$ 165$ & $\$ 180$ & $\$ 235$ & $\$ 240$ & $\$ 255$ & & & & Road trans $C_{i j}^{1}$ \\
\hline & \multicolumn{8}{|c|}{ Average transportation time } & \\
\hline & \multicolumn{8}{|c|}{$C_{i j}^{2}(\mathrm{~h} / \mathrm{piece})$} & \\
\hline Ws1 & $\mathrm{S} s_{1}$ & $\mathrm{~S}_{2}$ & $\mathrm{Ss}_{3}$ & $\mathrm{~S} s_{4}$ & $\mathrm{~S} s_{5}$ & $\mathrm{~S} s_{6}$ & $\mathrm{~S} s_{7}$ & $\mathrm{~S} s_{8}$ & \\
\hline \multirow[t]{3}{*}{ SOUTH KIVU } & 45 & 95 & 17 & 26 & 150 & 45 & 15 & 65 & SQ (piece) \\
\hline & - & 0.4 & 0.28 & - & 0.47 & 0.38 & - & 0.5 & Air trans $C_{i j}^{2}$ \\
\hline & 0.15 & 9.55 & 2.08 & 2.46 & 18.36 & 2.85 & 0.45 & 8.12 & Road trans $C_{i j}^{2}$ \\
\hline Ws2 & $\mathrm{S} n_{1}$ & $\mathrm{Sn}_{2}$ & $\mathrm{Sn}_{3}$ & $\mathrm{Sn}_{4}$ & $\mathrm{~S} n_{5}$ & $\mathrm{Sn}_{6}$ & & & \\
\hline \multirow[t]{3}{*}{ NORTH KIVU } & 40 & 110 & 52 & 35 & 65 & 70 & & & SQ (piece) \\
\hline & - & 0.55 & 0.5 & 0.32 & 0.42 & 0.32 & & & Air trans $C_{i j}^{2}$ \\
\hline & 0.75 & 4.81 & 4.02 & 4.58 & 10.63 & 4.16 & & & Road trans $C_{i j}^{2}$ \\
\hline Ws3 & $\mathrm{S} i_{1}$ & $\mathrm{~S} i_{2}$ & $\mathrm{Si}_{3}$ & $\mathrm{Si}_{4}$ & $\mathrm{Si}_{5}$ & & & & \\
\hline \multirow[t]{3}{*}{ ITURI } & 75 & 18 & 45 & 65 & 80 & & & & SQ (piece) \\
\hline & 0.3 & 0.4 & 0.5 & 0.3 & 0.4 & & & & Air trans $C_{i j}^{2}$ \\
\hline & 2.54 & 6.13 & 9.24 & 2.31 & 5.78 & & & & Road trans $C_{i j}^{2}$ \\
\hline
\end{tabular}

\subsection{Decision scenario 1: computing the transportation time and cost from available air links and from available connecting roads}

\subsubsection{Air links connectivity}

All candidate facility locations in each province are connected to their Chief Town either airplanes or by a Helicopters. To be noted that this study previously assumed that both airplanes and Helicopters were available to transport prepositioned goods. Table 11 shows the calculated supply transportation cost (\$) and time (days) for each candidate location. The outcome reveals that under the estimated air cost and supply quantity, it will take 17.41 days to air supply to all facility locations with the overall transportation cost of $\$ 28,826,745$.

\subsubsection{Road connectivity}

All candidate facility locations are connected to each province" chief town by trucks and other transportation modes that use roads. With the assumption that the region has enough available trucks at each province chief town, ready for transportation, goods are transported to destinations with the conditions that roads are in good condition and secure for goods and staffs. Other minor concern for road travelers includes health services and administrative officers. Table 12 reveals that under the estimated air cost 
Table 11 Average air transportation cost and average transportation time

\begin{tabular}{|c|c|c|c|c|c|c|c|c|c|c|c|c|}
\hline \multirow{2}{*}{$\begin{array}{l}\text { Warehouses } \\
\text { Supply code }\end{array}$} & & & \multicolumn{10}{|l|}{ W1 } \\
\hline & & & Ss1 & Ss2 & & s3 & Ss 4 & Ss 5 & \multicolumn{2}{|c|}{ Ss6 } & Ss7 & Ss8 \\
\hline \multicolumn{3}{|c|}{ Given average transportation time } & 0.15 & 9.55 & & 2.08 & 2.46 & 18.36 & \multicolumn{2}{|c|}{2.85} & 0.45 & 8.12 \\
\hline \multicolumn{3}{|c|}{ Given average transportation cost } & $\$ 145$ & $\$ 240$ & & $\$ 190$ & $\$ 200$ & $\$ 275$ & \multicolumn{2}{|c|}{$\$ 205$} & $\$ 150$ & $\$ 220$ \\
\hline \multicolumn{3}{|c|}{ Selected transport method } & Land & Land & & Land & Land & Land & \multicolumn{2}{|c|}{ Land } & Land & Land \\
\hline \multicolumn{3}{|l|}{ Max supply quantity } & 45 & 95 & & 17 & 26 & 150 & \multicolumn{2}{|c|}{45} & 15 & 65 \\
\hline \multicolumn{3}{|l|}{ Supply transport cost } & $\$ 6525$ & $\$ 22,80$ & & $\$ 3230$ & $\$ 5200$ & $\$ 41,25$ & \multicolumn{2}{|c|}{$\$ 9225$} & $\$ 2250$ & $\$ 14,300$ \\
\hline \multicolumn{3}{|l|}{ Transport time (hours) } & 6.75 & 907.25 & & 35.36 & 63.96 & 2754 & & 128.25 & 6.75 & 527.8 \\
\hline \multicolumn{3}{|l|}{ Transport time (days) } & 0.28 & 37.80 & & 1.47 & 2.67 & 114.75 & & 5.34 & 0.28 & 21.99 \\
\hline & \multicolumn{6}{|l|}{ W2 } & \multicolumn{5}{|l|}{ W3 } & \multirow[t]{2}{*}{ Total } \\
\hline & Sn1 & $\mathrm{Sn} 2$ & Sn3 & Sn4 & Sn5 & Sn6 & Sil & $\mathrm{Si} 2$ & $\mathrm{Si} 3$ & $\mathrm{Si} 4$ & $\mathrm{Si} 5$ & \\
\hline $\begin{array}{l}\text { Given average } \\
\text { transportation time }\end{array}$ & 0.75 & 4.81 & 4.02 & 4.58 & 10.63 & 4.16 & 2.54 & 6.13 & 9.24 & 2.31 & 5.78 & \\
\hline $\begin{array}{l}\text { Given average } \\
\text { transportation cost }\end{array}$ & $\$ 160$ & $\$ 210$ & $\$ 205$ & $\$ 225$ & $\$ 255$ & $\$ 230$ & $\$ 165$ & $\$ 180$ & $\$ 235$ & $\$ 240$ & $\$ 255$ & \\
\hline $\begin{array}{l}\text { Selected transport } \\
\text { method }\end{array}$ & Land & Land & Land & Land & Land & Land & Land & Land & Land & Land & Land & \\
\hline Max supply quantity & 40 & 110 & 52 & 35 & 65 & 70 & 75 & 18 & 45 & 65 & 80 & \\
\hline $\begin{array}{l}\text { Supply transport } \\
\text { cost }\end{array}$ & $\$ 6400$ & $\$ 23,100$ & $\$ 10,660$ & $\$ 7875$ & $\$ 16,575$ & $\$ 16,100$ & $\$ 12,375$ & $\$ 3240$ & $\$ 10,575$ & $\$ 15,600$ & $\$ 20,400$ & $\$ 2,47,680$ \\
\hline $\begin{array}{l}\text { Transport time } \\
\text { (hours) }\end{array}$ & 30 & 529.1 & 209.04 & 160.3 & 690.95 & 291.2 & 190.5 & 110.34 & 415.8 & 150.15 & 462.4 & Max time \\
\hline $\begin{array}{l}\text { Transport time } \\
\text { (days) }\end{array}$ & 1.25 & 22.05 & 8.71 & 6.68 & 28.79 & 12.13 & 7.94 & 4.60 & 17.33 & 6.26 & 19.27 & 319.58 \\
\hline
\end{tabular}

and supply quantity, it will 319.58 days to transport by road all the relief supply to facility locations with the overall transportation cost of $\$ 247,680$. Close studies to the Table 12, few bottlenecks in term of transportation time surfaces. Among them, the Table 12 shows that it takes 114.75 days to supply relief to Shabunda (Ss5) alone from Bukavu (W1) due to poor road condition.

The graph below (Fig. 6) shows that transporting goods via road is way cheaper than transporting goods via air although it takes longer than it should due to the poor road conditions. As mentioned, from Bukavu (W1) to Shabunda (Ss5) road condition was described on the evaluation Table 7 as "critical". Such road had led to the increase of transportation Time and Cost while other long-distance road to Walikale (Sn5), with a "fair" road (Table 7) from Goma (W2) has been reach quicker. Both Figs. 6 and 7 show respectively that road transportation is cheaper and longer than the Air transportation.

Both road and air connectivity offer a contrasting outcome to the research intent. The next decision scenario intends to minimize both road and the air transportation.

\subsection{Decision scenario 2: computing the transportation time and cost based on the province by province evaluation of road conditions, administrative offices, security and health (as stated in Table 7)}

The decision scenario intends to use the outcome of the first scenario in order to development a model that minimizes the cost and the time. Scenario one first revealed that road transportation is ideal for the humanitarian delivery for many reasons: (1) all facility locations are connected by road, (2) road transportation is cheaper. However, road transportation in DRC brings along many challenges, among many road conditions and the security of goods humanitarian personnel's during the operation. In order to alleviate these challenges, this research developed a framework in the Table 6 that evaluates each of these challenges and scale them from "good" to "critical". Then Table 7 evaluates each facility locations targeted in this study and each area was scaled according to the challenge it is facing at the time this study is conducted. In the next point, the list of challenges scaled in Table 7 is analyzed 


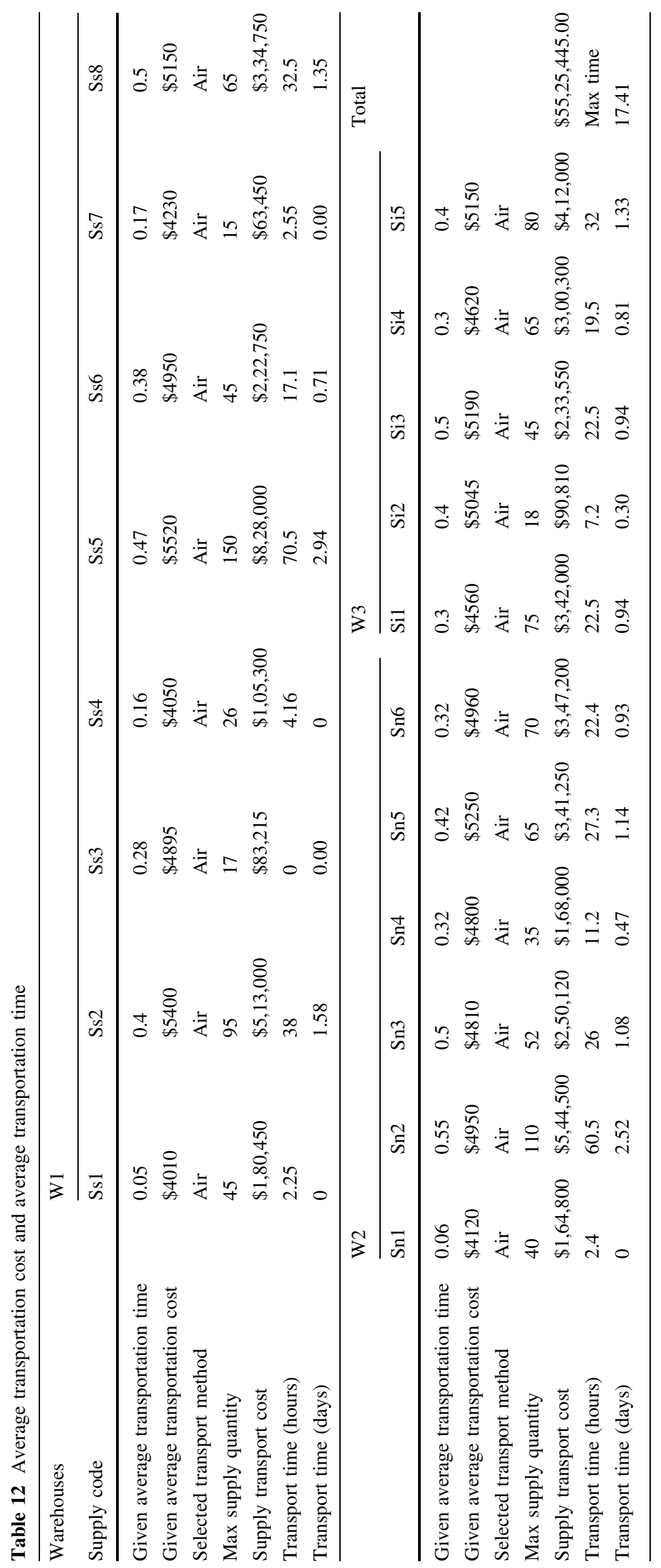


Fig. 6 Road transportation cost versus air transportation cost (\$)
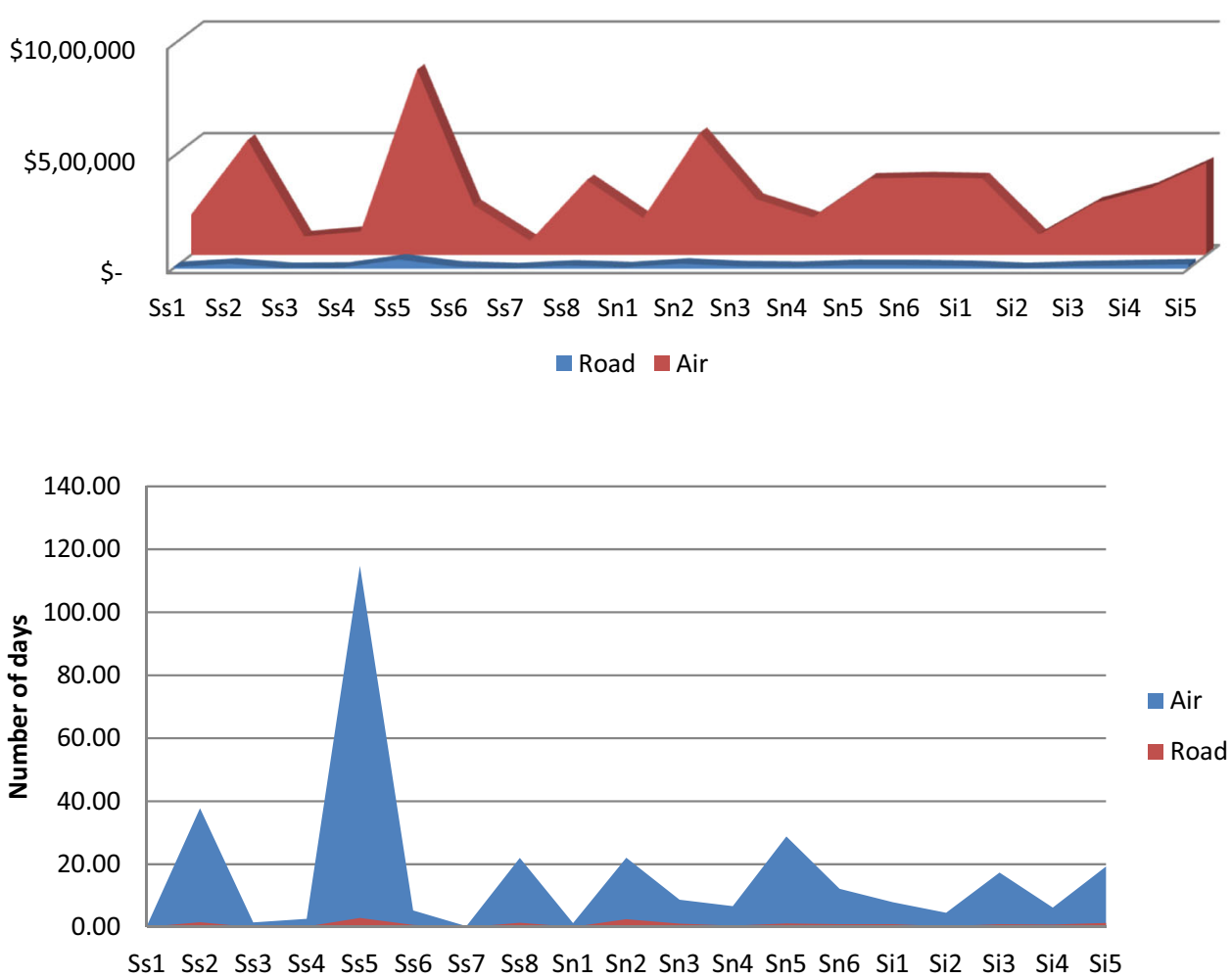

Fig. 7 Road transportation versus air transportation time (days)

Table 13 Counting of evaluated areas in Table 3.7

\begin{tabular}{|c|c|c|c|c|c|}
\hline & Good & Fair & $\mathrm{Bad}$ & Critical & Total \\
\hline Road conditions & $\begin{array}{l}\text { Sn1, Sn2, } \\
\quad \text { Sn3 }\end{array}$ & Ss1, Ss3, Ss4, Ss6, Ss7, Sn4, Sn5, Sn6, Si1, Si3, Si5 & Ss2, Ss8, Si2, Si4 & Ss5 & 19 \\
\hline $\begin{array}{l}\text { Administrative } \\
\text { offices }\end{array}$ & Ss1, Sn1, & $\begin{array}{l}\text { Ss2, Ss3, Ss4, Ss6, Ss7, Sn2, Sn3, Sn4, Sn5, Sn6, Si1, } \\
\text { Si2. Si3, Si5 }\end{array}$ & Ss5, Ss5 & $\mathrm{Si} 4$ & 19 \\
\hline Security & Ss1, Sn1, & Ss2, Ss3, Ss4, Ss5, Ss7, Si1, Si3 & Ss6, Sn2, Sn3, Sn4, Si2 & $\begin{array}{l}\text { Ss8, Sn5, } \\
\text { Sn6, Si4 }\end{array}$ & 19 \\
\hline Health & Ss1, Sn1, & Ss3, Ss4, Ss6, Ss7, Sn4, Si1, Si2. Si3 & $\begin{array}{l}\text { Ss2, Ss5, Ss8, Sn2, Sn3, Sn5, } \\
\text { Sn6, Si5 }\end{array}$ & $\mathrm{Si} 4$ & 19 \\
\hline Total & 9 & 40 & 19 & 7 & 76 \\
\hline
\end{tabular}

and the feedback is useful in determining areas that are not "road worthy" and that require different modes.

\subsubsection{Analysis of the evaluation}

Table 13 below shows the list of key challenges faced by relief organizations during humanitarian supply chain and what category each area is scaled under. For instance, the "road condition" challenge fall under a "good" scale in Goma (Sn1), Beni (Sn2) and Butembo (Sn3) while the scale was "critical" in Shabunda (Ss5). In total, Table 13 shows that most road conditions, administrative offices, security and health care facilities in the areas being studied are "fair" with $52.63 \%$, while the "good" are $11.84 \%$, "Bad" $25 \%$ and "critical" $9.21 \%$.

Table 14 below shows the percentage for scale according to the challenge. This exercise allows the research to identify the percentage each challenge has on the total number of areas being targeted. For instance, $21.05 \%$ of humanitarian supply chain operation is operated under "critical" security threat due to the conflicts faced in the region.

A prepositioned humanitarian supply chain in a conflict zone requires all listed challenges in Table 14 being taken into accounts. However, when zooming into the transportation of humanitarian reliefs by roads from a source to 
Table 14 Identification of each scale percentage

\begin{tabular}{llllcc}
\hline & Good $(\%)$ & Fair $(\%)$ & Bad $(\%)$ & Critical $(\%)$ & Total $(\%)$ \\
\hline Road conditions & 15.80 & 57.90 & 21.05 & 5.30 & 100 \\
Administrative offices & 10.52 & 73.68 & 10.52 & 5.30 & 100 \\
Security & 10.52 & 36.84 & 26.31 & 21.05 & 100 \\
Health & 10.52 & 42.11 & 42.11 & 5.30 & 100 \\
Total & 11.84 & 52.63 & 25 & 9.21 & 100 \\
\hline
\end{tabular}

destinations, two key challenges are necessary to take into account among the four challenges are the "road conditions" and the "security". Looking into the road condition, Table 14 shows that $73.70 \%$ of roads are in the "good" to "fair" condition while the remaining $26.3 \%$ were "bad" to "critical" condition. Furthermore, only $47.36 \%$ of road transportation to facility locations is view as done in "good" security and "fair" security. Unfortunately, most facility locations (52.64\%) are located in areas that do not guarantee security to humanitarian goods and personnel.

\subsubsection{Application of the evaluation}

In order to ensure the safety of the reliefs, the goods are delivered at the minimum costs and time; this study has applied the evaluation outcomes defined in Tables 13 and 14 into the road and Air transportation results found in Tables 11 and 12. By integrating the road conditions" and the "Security" evaluation into the model, the research minimizes both costly and lengthy deliveries while ensuring that reliefs reaches destinations safely. Such is achieved by prioritizing road deliveries to all destination cities except in the case of "bad" or "critical" road conditions and deliveries to unsafe areas. Table 15 and Fig. 8 show that by opting for air transportation in the delivery to areas with "bad" to "Critical" road conditions, or to those with record security

Table 15 Outcomes of both decision scenarios

\begin{tabular}{lrc}
\hline & Price $(\$)$ & Time (day) \\
\hline Air transportation & $\$ 28,826,745$ & 17.63 \\
Road transportation & $\$ 247,680$ & 319.58 \\
Air and road combined & $\$ 2465,105$ & 127.25 \\
\hline
\end{tabular}

challenges, the Transportation price increases from $\$ 247,680$ to $\$ 2,465,105$ while the delivery time decreases from the initial 320 days to 128 days. Combining however Air Transportation to the Road Transportation to challenged places decreases the air transportation cost from $\$ 28,826,745$ to a combined cost of $\$ 2,465,105$.

\section{Conclusion and future works}

Both Road and Air connectivity offer a contrasting outcome to the research objectives. For the Road transportation, although cheaper and ideal for the "cash trapped" humanitarian relief operations, it takes longer to deliver goods due to poor road conditions at some trajectories while the relief security also represent a serious challenge. The Air Transportation, although it ensures that goods are delivered safely, efficiently and at a small-time frame, however it is too pricy.

With this research intent of prepositioning goods transported to facility locations, there is therefore no rush to use air transportation with its benefices of being faster and reliable but also its consequences of costing nearly 12 times more than road transportation. With prepositioned facility locations, road transportation, except in the case of poor road conditions or lack of security to staff and goods, should be the main transportation mode especially during humanitarian supply chain. This study outcomes shows that (1) by using roads to areas evaluated as "good" or "Fair" and (2) by opting for air transportation to areas evaluated as "Bad" or "critical" and those with the record of security issues, this research will minimize the transportation time and the cost simultaneously.

Like the Democratic Republic of Congo, many countries and region in the world are struggling with conflicts that
Fig. 8 Price versus time of air, road and both combined transportation

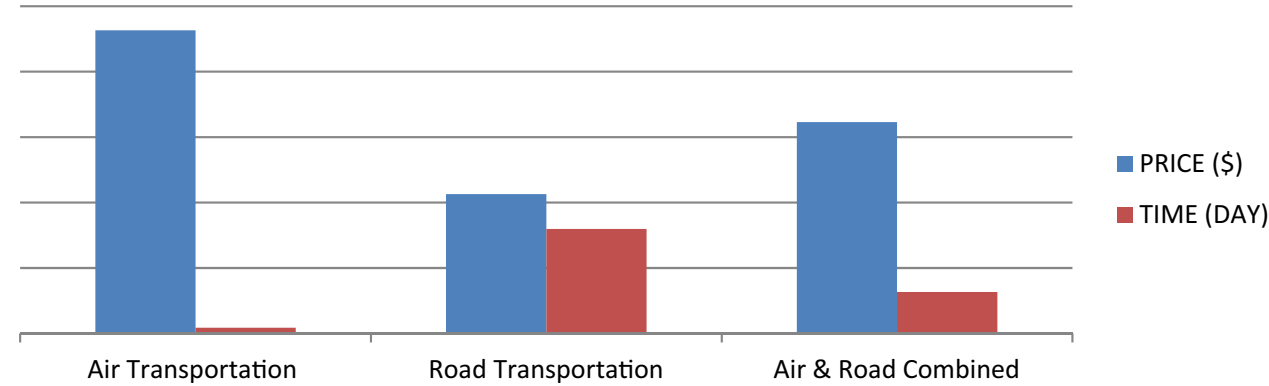


has caused logistical and supply chain challenges. Applying this model not only minimises the time and cost for transportation, but also assist decision makers select the best relief transportation decisions.

Future works may improve the feasible solution by looking into the unbalanced transportation problems in case which total demand is not equal to the total supply. For instance, when demand is less than supply or when the demand is greater than supply. Other areas of interest in future studies are in incorporating all key humanitarian supply chain challenges listed in this study into one model. Also, researches could look at the risk of delivering relief by road despite of the $52.64 \%$ security threat faced by humanitarian goods and personnel.

\section{References}

Balcik B, Beamon BM (2008) Facility location in humanitarian relief. Int J Logist Res Appl 11(2):101-121

Beamon BM (2004) Humanitarian relief chains: issues and challenges. In: Proceedings of the 34th international conference on computers and industrial engineering, vol 34 , issue 1 . University of Washington, Seattle, WA, pp 77-82

Campbell AM, Jones PC (2011) Prepositioning supplies in preparation for disasters. Eur J Oper Res 209(2):156-165

Caunhye AM, Nie X, Pokharel S (2011) Optimization models in emergency logistics: a literature review. Soc Econ Plan Sci 41(1):4-13

Centre of research on the Epidemiology of Disasters Website (EMDAT CRED) (2016) Southern Africa disasters database. 26 Sep 2013. http://www.em-dat.net

Counsel of Foreign Relations (2020). https://www.cfr.org/interactive/ global-conflict-tracker/conflict/violence-democratic-republiccongo. Accessed 15 Jan 2020

Degener P, Gösling H, Geldermann J (2013) Decision support for the location planning in disaster areas using multi-criteria methods. In: International ISCRAM conference, vol 10, issue 1. BadenBaden, Germany, pp 278-283

Duran S, Keskinocak P, Gutierrez MA (2011) Pre-positioning of emergency items worldwide for CARE international. Pre-position Emerg Suppl 41(3):223-237

Hale T, Moberg CR (2005) Improving supply chain disaster preparedness: a decision process for secure site location. Int $\mathbf{J}$ Phys Distrib Logist Manag 35(3):195-207

International Monetary Fund (2019) Democratic republic of Congo. IMF Country. Report No. 19/286

Jimenez F, Verdegay JL (1998) Uncertain solid transportation problems. Fuzzy Sets Syst 100(1):45-57

Kembro J (2012) Implementing strategic stock to improve humanitarian aid response. Emerald Emerg Mark Case Stud 2(7):1-6

Kim BS, Opit PF, Lee WS (2011) A stock prepositioning model to maximize the total expected relief demand of disaster areas. Oper Supply Chain Manag 6(2):103-110

Kovács G, Spens KS (2009) Identif Chall Humanit Logist 39(6):506-528

Kunz N, Reiner G, Gold S (2013) Investing in disaster management capacities versus pre-positioning inventory: a new approach to disaster preparedness. Int J Prod Econ 157(1):261-272
Mpita SN, Yadavalli VSS, Bean WL (2016) Integrated facility location planning and demand assessment for humanitarian logistics: a case study in the Democratic Republic of the Congo. Manag Dyn 25(1):34-50

Nahleh Y, Kumar A, Daver F (2013) Facility location problem in emergency, international journal of mechanical, aerospace, mechatronic, and manufacturing. Engineering 7(10):2113-2118

OCHA (United Nations Office for the Coordination of Humanitarian Affairs) RDC (2019) Ebola in the Democratic Republic of the Congo. Health emergency update. https://www.who.int/emergen cies/diseases/ebola/drc-2019. Accessed 15 Jan 2020

Oxfam International (2014) Oxfam annual report 2014-2015. https:// www-cdn.oxfam.org/s3fs-public/file_attachments/story/oxfam_ annual_report_2014_-_2015_final.pdf

Prasad VR, Nair KPK, Aneja YP (1993) A generalized time-cost trade-off transportation problem. J Oper Res Soc 1243-1248

Ranganathan R, Foster V (2011) The SADC''s infrastructure: a regional perspective. Policy research. World Bank, Africa Region

RDC Humanitaire (2020) (online). https://www.humanitairanre sponse.info/fr/operations/democratic-republic-congo. Accessed 15 Jan 2020

Roh S, Jang H, Han C (2013) Warehouse location decision factors in humanitarian relief logistics. Asian J Shipp Logist 29(1):103-120

Root S, Qu X, Samanlioglu F, Davis L (2012) Inventory planning and coordination in disaster relief efforts. Int $\mathrm{J}$ Prod Econ 141(2):561-573

Starr MK, Van Wassenhove LN (2014) Introduction to the special issue on humanitarian operations and crisis management. Production operations and crisis management. Prod Oper Manag 23(6):925-937

Strawderman L, Eksioglu B (2009) The role of intermodal transportation in humanitarian supply chains final report

Tatham P, Houghton L (2011) The wicked problem of humanitarian logistics and disaster relief aid. J Humanit Logist Supply Chain Manag 1(1):15-31

Thomas A (2004) Elevating humanitarian logistics. Int Aid Trade Rev 1(1):102-106

Timperio G, Panchal GB, Samvedi A, Goh M, De Souza R (2017) Decision support framework for location selection and disaster relief network design. J Humanit Logist Supply Chain Manag 7(3):222-245

Tomasini RM, Van Wassenhove LN (2009) From preparedness to partnerships: case study research on humanitarian logistics. Int Trans Oper Res 16(5):549-559

Turnquist MA, Rowls CG (2009) Pre-positioning of emergency supplies for disaster response. Transp Res Part B 44(4):521-534

Van Wyk E, Yadavalli VSS, Carstens H (2013) Decision support in supply chain management for disaster relief in Somalia. In: New paradigms in internet computing, vol 1, issue 1. Springer, Berlin, Heidelberg, pp 13-22

WFP (2012) Concept of operations-DRC North and South Kivu. World Food Programme (online). http://www.logcluster.org/ sites/default/files/documents/conops-north-and-south-kivu121205. Accessed 11 Nov 2015

WFP (2013). https://reliefweb.int/sites/reliefweb.int/files/resources/ sigma1_2016_en.pdf. Accessed 15 Mar 2020

World Bank (2020) (Online). https://www.humanitairanresponse.info/ fr/operations/democratic-republic-congo. Accessed 15 Jan 2020

World Vision (2018). https://www.worldvision.org/disaster-reliefnews-stories/worst-disasters-2018. Accessed 15 Jan 2020

Publisher's Note Springer Nature remains neutral with regard to jurisdictional claims in published maps and institutional affiliations. 